\title{
Studies on Citrus Melanose and Citrus Stem-End Rot by Diaporthe citri (Faw.) Wolf. Part 7. Function of Epidermal Cell in the Self-Defense Reaction of Citrus Plant
}

\author{
Yutaka Arimoto and Yasuo Homma
}

\begin{abstract}
Presence of epidermal cell was essential for the induction of self-defense reaction of citrus plants when inoculated with Diaporthe citri (Faw.) Wolf. If the epidermis was removed from the plant, the self-defense reaction did not occur even if mesophyll was inoculated with the fungus or wounded with a knife mechanically. This suggests that a inducer of self-defense reaction exists in the epidermal cell, and is activated when those cells are damaged. When the self-defense reaction did not induce by penetration with $D$. citri due to removal of epidermis, fungus spread inside the tissues, and pycnidia and sporehorn were formed.
\end{abstract}

(Received July 24, 1986)

Key words : citrus melanose, self-defense reaction, Diaporthe citri.

\section{Introduction}

Diaporthe citri (Faw.) Wolf causes two different diseases of citrus, melanose to form a superficial blemish on fruit, leaves and shoots, and the other stem-end rot to decay fruit mainly after harvest. Both diseases are very important in Japan ${ }^{9-14)}$

A previous report showed that the hyphae of $D$. citri penetrated through cuticle and then reached inside the epidermal cells of fruit, leaves and shoots of satsuma mandarin (Citrus unhsiu Marc.). The invaded hyphae of pathogen into the epidermal cells was arrested and then killed in the cells ${ }^{1)}$. The epidermal cell of fruit, leaves and shoots penetrated by the hyphae of the fungus were granulated and turned brown. Further granulation and browning of cell components occurred around the initially infected epidermal cell, and a group of browned cells consisted of 3 to 5 cell layers formed in a semispherical shape around the initially infected epidermal cell. After that, division of cells adjacent to the browned cells repeatedly occurred to form a cork tissue consisting of 10 to 12 cell layers around the browned cells. Thus the melanose spot was finally formed by a browned cells and a cork tissue. Star melanose caused by phytotoxicity of copper compound and scar caused by mechanical injury developed also in a similar fashion to that of melanose spot, consisting of browning cells and a cork tissue. This

RIKEN (The Institute of Physical and Chemical Research), 2-1 Hirosawa, Wako-Shi, Saitama 35101, Japan 理化学研究所 
phenomenon means that melanose spot forms as the results of a reaction responded to the stimulation with penetration of $D$. citri. The reaction seems to be a self-defense reaction against infection with the fungus ${ }^{2,3)}$.

The investigation was performed to clarify the function of the epidermal cell in the self-defense reaction of citrus plants.

\section{Materials and Methods}

Inoculation test. By stripping the epidermis of the leaves of greenhouse-grown satsuma mandarin (Citrus unshiu Marc.), the mesophyll about $3 \mathrm{~cm} \times 2 \mathrm{~cm}$ was exposed (Sleaf). Pycnospore suspension $(20 \mu 1)$ of $D$. citri prepared by the usual methods was placed on the exposed mesophyll of S-leaf and on the epidermis of untreated leaf (N-leaf) with a microsyringe $\mathrm{e}^{1-3,5,6,9,10)}$. After keeping the inoculated trees in a moist chamber (R. H. : 100\%, Temp.: $25 \mathrm{C}$ ) for two days, they were transferred to a greenhouse. The inoculated leaves were detached from the plant after a week and kept them in a moist Petri dish.

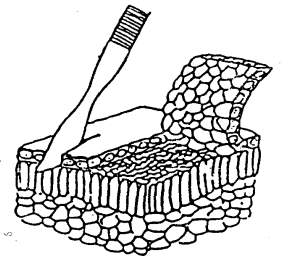

1

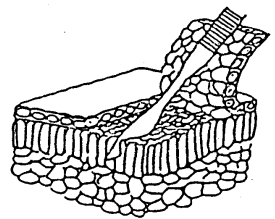

2

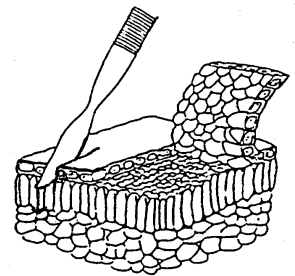

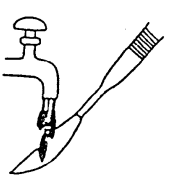

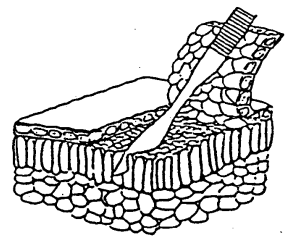

3

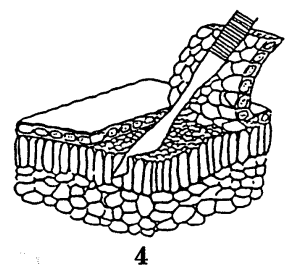

Fig. 1. Procedure of injury.

1. Untreated leaf having epidermis was injured with a razor knife.

2. Mesophyll of epidermis-stripped leaf was directly injured with a razor knife.

3. Mesophyll of epidermis-stripped leaf was injured with the razor knife which previously cut untreated part having epidermis.

4. Mesophyll of epidermis-stripped leaf was injured with the razor knife that had been washed with tap water immediately after cutting untreated parts having epidermis. 
Mechanical injury test. In order to clarify the role of the epidermal cell in the self-defense reaction, four treatments were done using $\mathrm{S}-$ and $\mathrm{N}$ - leaves as shown in Fig. 1. Treatment 1: N-leaf having epidermis was injured with a knife (E-Injury). Treatment 2: mesophyll of S-leaf was directly injured with a knife (M-Injury). Treatment 3: mesophyll of S-leaf was cut with the knife that had cut $\mathrm{N}$-leaf and been contaminated with $\mathrm{N}$-leaf sap (M(E)-Injury). Treatment 4: mesophyll of S-leaf was injured with the knife that had been washed with water immediately after cutting $\mathrm{N}$-leaf ( $\mathrm{M}(\mathrm{E}-\mathrm{Wash}$ )-Injury). After treatments, the plants were transferred to a greenhouse, and the changes at injured sites were periodically observed.

Microscopic observation. The treated host tissues and thin sections of these tissues prepared using freezing microtome were observed under an optical microscope and a scanning electron microscope.

\section{Results}

\section{Inoculation test}

When pycnospore suspension of $D$. citri was directly placed on the mesophyll of S-leaf, about 90\% spores germinated one day after inoculation. They developed superficial hyphae on the tissue, and the hyphae elongated under the epidermis two days after inoculation (Plate I-1). However, no mesophyll cells changed their color, and no melanose spots developed two weeks after inoculation (Plate I-2). A part of cells of mesophyll turned brown caused by a mechanical injury when epidermis was stripped (Plate I-2, arrows).

On the other hand, when spore suspension was placed on the epidermis of N-leaf, about 15\% spores germinated one day after inoculation. The hyphae of the fungus penetrated into the epidermal cell, and the initially infected epidermal cell was granulated after one day. These granulated epidermal cells turned brown in color after three days. The number of browned cells increased in the surrounding area of the initially infected epidermal cell. After that the cells adjacent to the browned ones divided irregularly. The cell division occurred repeatedly, and melanose spot was formed on the N-leaf (Plate I-2).

$\mathrm{S}-$ and $\mathrm{N}$-leaf were detached from the citrus plant a week after the inoculation, and incubated under the moist chamber at $25 \mathrm{C}$. The inoculated part of S-leaf was decomposed two days after incubation, and whole leaf decomposed finally. Elongation of superficial hyphae of $D$. citri was observed on the decomposed leaf. Pycnidia and spore-horn were formed on the leaf 7 days after incubation (Plat I-3).

However, the $\mathrm{N}$-leaf was not decomposed 14 days after incubation, and no superficial hyphae of $D$. citri were also observed on the surface.

\section{Mechanical injury test}

1) E-Injury

By mechanical injury of $\mathrm{N}$-leaf having epidermis, the cells in an incised part of the leaf turned brown, and also the adjacent cells to the browned ones divided abnormally (Plate I-4). 
2) M-Injury

By direct injury of mesophyll tissue having no epidermis, any cells in an incised part of mesophyll did not change in color, and no cell division occurred (Plate I -5).

3) $\mathrm{M}(\mathrm{E})$-Injury

Mesophyll cells in an incised part of leaves turned brown in color one day after treatment. Thereafter, the cells adjacent to the browned cells divided (Plate I-6).

4) $\mathrm{M}(\mathrm{E}-$ Wash)-Injury

Mesophyll cell in an incised part of leaves did not change in color, and no cell division occurred (Plate $\mathrm{I}-7$ ).

\section{Discussion}

Fruit, leaves and shoots responded through following process against infection of D. citri, the first was granulation and browning of the infected epidermal cell, the second was granulation and browning of the cells around the initially browned epidermal cell, and the last was a cork tissue formation by cell division. Star melanose caused by phytotoxicity of copper compounds and scar caused by mechanical injury were also formed in a similar manner to that of melanose, and consisted of browned cells and a cork tissue ${ }^{1,2)}$.

Since, this phenomenon means dynamic defense structure that develop in tissue as a response to pathogen invasion, it is believed that the response seems to be a selfdefense reaction of fruit, leaves and shoots of satsuma mandarin ${ }^{1,2)}$.

The center of defense tissue, i. e. melanose spot, was always the initially infected cells of epidermis ${ }^{1-3)}$. These results suggest that the epidermal cell plays an important part in the self-defense reaction. To clarify the function of the epidermal cell in the self-defense reaction, a series of experiments was conducted using the leaves whose epidermis was removed.

Since the pathogenic fungus, $D$. citri, penetrated directly into cells of mesophyll of the epidermis-stripped leaf, the self-defense reaction was not induced. Though the self-defense reaction was induced by the treatment with E-injury and $M(E)$-injury, but not with $\mathrm{M}$-injury and $\mathrm{M}(\mathrm{E}$-wash)-injury. These results suggest that self-defense reaction closely related to presence of epidermis. And its inducer would distribute only in the epidermal cell. The inducer was activated when the epidermal cell was infected by hyphal penetration or by mechanical injury.

When an epidermal-stripped leaf (S-leaf) was inoculated with D. citri, the whole of $\mathrm{S}$-leaf was decomposed. In contrast, $\mathrm{N}$-leaf having epidermis was not decomposed, and the hyphal invasion was limited as formation of the melanose spot. This phenomenon means that the self-defense reaction of a citrus plant is very important to inhibit further spread of the hyphal invasion.

Homma et al. reported that D. citri hyphae penetrated into peduncle tissues and bearing shoot of a citrus plant in a late growing season of fruit, and reached fruit button $^{8}$. However, when the pathogen penetrated into epidermis of fruit, leaves and new shoots, it was arrested in the first penetrated epidermal cell ${ }^{1,2}$. The reason why $D$. 
citri is able to penetrate into peduncle and bearing shoot seems to be due to the fact that the parts of citrus tree have many cracks on the surface, where no epidermal cells exist. Thus the pathogen can penetrate directly into mesophyll cell without encountering self-defense reaction of plant, spreading further in the tissue.

\section{Literature cited}

1. Arimoto, Y., Homma, Y. and Misato, T. (1980). Ann. Phytopath. Soc. Japan $46: 575-581$.

2. Arimoto, Y., Homma, Y. and Misato, T. (1982). Ibid. 48:559-569.

3. Arimoto, Y., Homma, Y. and Misato, T. (1986). Ibid. $52: 39-46$.

4. Bach, W. J. and Wolf, F. A. (1928). J. Agr. Res. $37: 243-253$.

5. Homma, Y. and Yamada, S. (1969) Bull. Hort. Res. Stn. B9 : 85-97.

6. Homma, Y. and Yamada, S. (1969). Ibid. B9: 99-113.

7. Homma, Y., Arimoto, Y. and Misato, T. (1979). Ann. Phytopath. Soc. Japan 45:9-16.

8. Homma, Y., Arimoto, Y. and Misato, T. (1985). Ibid. $51: 324$.

9. Kuramoto, T. and Yamada, S. (1975). Bull. Fruit Tree Res. Stn. B2 :75-86.

10. Tanaka, S. and Nakamura, S. (1950). J. Japan Soc. Hort. Sci. $19: 177-184$.

11. Ushiyama, K. (1971). Bull. Kanagawa Hort. Exp. Stn. $19: 29-37$.

12. Ushiyama, K. (1973). Ibid. $21: 39-46$.

13. Ushiyama, K. (1976). Ibid. $23: 11-18$.

14. Yamada, S. and Yamamoto, S. (1961). Bull. Hort. Res. Stn. B6 : 108-116.

\section{和 文 摘 要}

有本 裕, 本間保男 : Diaporthe citri によるカンキツ黒点病ならびに軸腐病に関する研究 第 7 報カンキツ の自己防衛反応に找ける表皮細胞の役割

カンキツ黒点病は Diaporthe citri の侵入により誘導される防衛反応の結果として形成されるむのであり, 病原菌は病斑内に封じ込められる。カンキツの自己防衛反応には表皮細胞が必須であり, 表皮細胞を除くと病 原菌の侵入をうけても自己防衛反応は起てらない。乙れは，自己防衛反応を誘起する因子は表皮細胞中にのみ 分布しており，表皮細胞が傷をうけると活性化され，その作用で誘起されるためと考えられた。D. citri の侵 入に対し, 自己防衛反応を行うととができないと, 病原菌は宿主内で蔓延し，ついには柄子殼や柄胞子を形成 する。すなわち, 自己防衛反応による防衛組織である黒点病斑は侵入病原菌の封じ込めに極めて有効である。

\section{Explanation of plate}

\section{Plate I}

1. Pycnospore suspension of D. citri was placed onto the mesophyll of epidermis-stripped leaf. Pycnospores germinated and germ tube elongated under the epidermis (two days after inoculation).

2. Pycnospore suspension of D. citri was placed into the circles on the mesophyll of epidermis-stripped part ( $\mathrm{m}$ ) or on epidermis of untreated part (e) of a leaf. Melanose spots were developed on the untreated part, but not on the epidermis-stripped part (two weeks after inoculation). A part of cells of mesophyll turned brown caused by a mechanical injury when epidermis was stripped (arrows).

3. Pycnidia of D. citri were formed on the epidermis-stripped leaf that had been inoculated, detached from the tree one week later and followed by incubation in a moist chamber for 7 days.

4. By a mechanical injury of untreated leaf with epidermis, the cells in an incised part of leaf turned brown, and the cells adjacent to the browned cells were divided (=selfdefense reaction) (7 days after injury).

5. When mesophyll of epidermis-stripped leaf was directly injured, no cells in an incised part of leaf turned brown, and no cell division occurred (7 days after injury).

6. A self-defense reaction was induced in the wounded parts of a epidermis-stripped leaf which was injured with the razor knife which had been contaminated with un- 
treated leaf's sap (7 days after injury).

7. No self-defense reaction was induced on the wounded parts of the epidermis-stripped leaf which was injured with the razor knife that had been washed with water immediately after cutting untreated leaf (7 days after injury).
Abbreviation
$\mathrm{bc}=$ browned cell, $\quad \mathrm{dc}=$ irregularly divided cell
$\mathrm{e}=$ epidermis, $\quad \mathrm{gt}=$ germ tube,
$\mathrm{m}=$ mesophyll,
$\mathrm{p}=$ pycnospore,$\quad \mathrm{w}=$ wound 


\section{Plate I}
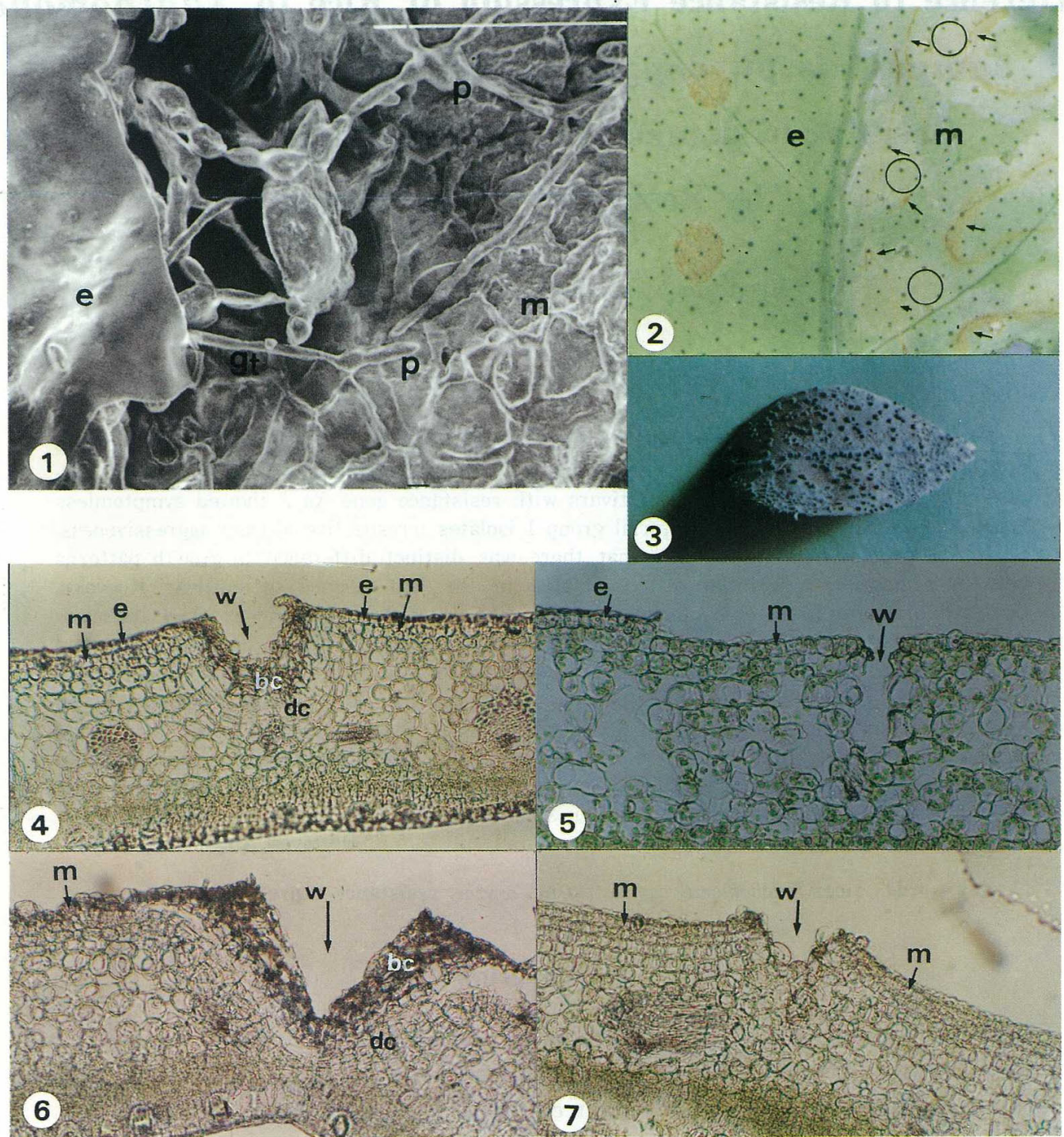